\title{
Analysis of the Main Causes of the Imbalance of International Payments and Risk Prediction
}

\author{
Huang Shaowei ${ }^{1,}{ }^{*}$, Zhang Jixiang ${ }^{2}$ \\ College of Economic and Management \\ Nanjing University of Aeronautics and Astronautics, Nanjing 210016, China \\ Email: 15851866171@163.com
}

\begin{abstract}
As an important variable of national economy, the balance of payments reflects the transnational flow of physical resources. Therefore, it is very important to predict the risk of the imbalance of international payments. Based on the balance of payments data from 2003 to 2012 in China, this paper uses the method of principal component analysis to predict the risk of China's international balance of payments. According to the analysis, three principal components are obtained, which show the relationship among the balance of payments risk and the trade balance, the money supply and the foreign net assets. Based on the results of principal component analysis and the international balance of payments risk index and its critical value, this paper provides some suggestions for the management of the imbalance risk of international payments in china.
\end{abstract}

Keywords: Balance of international payments. Risk forecast. Principal component analysis.

\section{Introduction}

Economic imbalance is a prominent problem in the current global economy, imbalance of international payments is an important cause and performance of international economic imbalance. In recent years, the balance of payments accounts that reflect China's foreign economic exchanges have become more and more imbalanced. China's two basic accounts of balance-payments current account and capital account simultaneously have long-term sustained surplus, which are so-called "double surplus."[1] The surplus scale of current account which is in the core status is soaring rapidly, and is becoming the most concentrated and true portrayal of the problem in China. China's long-term and large-scale "double surpluses" in the balance of payments have been gradually formed and deepened in the process of China's economic reform and opening up, especially since the mid-1990s. Facing this increasingly serious "external" imbalance in the Chinese economy, if we do not pay attention or have regulation, the problem will go to its opposite. Therefore, it is very important to forecast the imbalance risk of international payments. Through the results of the forecast we can take some measures to avoid a lot of unnecessary losses.

At present, many scholars have studied the causes of the imbalance of China's international payments from the perspective of balance of payments [2-6] and income distribution [7], and put forward corresponding countermeasures; some scholars make research by combining the imbalance of international payments with industrial structure [8] and the quality of economic growth [9-10], or establish the risk warning system of imbalances of international balance of payments [11].The number of indicators of the balance of international payments is very large, and there is a strong correlation among these indicators. Based on China's international balance of payments data from 2003 to 2012, this paper uses the principal component analysis method [12] and proposes three principal components from the international balance of payments index to express the impact of each index on the balance of payments. The three principal components assembly most of the information of the original indicators. The problem is simplified by the technology of reduced dimension and this method reflects the main direction and strategy of macro regulation and control from a certain extent. Finally, this paper has risk budget for future years' balance of payments according to the balance of payments risk index. This paper verifies the model based on the data of international balance of payments in 2014. 


\section{Establishment and Solution of the Model}

In order to analyze the problem comprehensively and systematically, many indexes must be considered. These indicators can reflect some characteristics of the research object from different aspects, and to some extent these information is correlated. The principal component analysis is a comprehensive statistical method which can convert multiple indicators into a few comprehensive indexes, which can reflect most of the information of the original indicators. Therefore, this paper first calculates the correlation coefficient matrix among the indicators, analyzes the correlation degree, and then derives a few principal components to find the comprehensive index of the balance of international payments risk. So we can combine China's international balance of payments risk index and its critical value to forecast future's risk of balance of payments.

China's international balance of payments in 2003-2012 is shown in Table 1:

Table 1 Balance of Payments from 2003 to 2012

\begin{tabular}{|c|c|c|c|c|c|c|c|}
\hline Years & $\begin{array}{l}\text { Current } \\
\text { account }\end{array}$ & Import & Export & Services & Income & $\begin{array}{l}\text { Current } \\
\text { transfer }\end{array}$ & $\begin{array}{c}\text { Capital \& } \\
\text { financial account }\end{array}$ \\
\hline 2003 & 205.2 & 2491.3 & 2146.6 & -56 & -146.7 & 63.1 & 19.2 \\
\hline 2004 & 174.1 & 2660.8 & 2320.6 & -59.3 & -191.7 & 84.9 & 347.8 \\
\hline 2005 & 354.2 & 3256.5 & 2814.8 & -67.8 & -149.5 & 129.8 & 322.9 \\
\hline 2006 & 458.7 & 438.3 & 393.6 & -85.7 & -78.4 & 176.3 & 527.3 \\
\hline 2007 & 686.6 & 593.4 & 534.4 & -97 & -35.2 & 229 & 1106.6 \\
\hline 2008 & 1608.2 & 7624.8 & 6282.9 & -93.9 & 106.4 & 253.9 & 629.6 \\
\hline 2009 & 2532.7 & 9696.8 & 7519.4 & -88.3 & 151.6 & 292 & 66.6 \\
\hline 2010 & 3718.3 & 12000 & 9046.2 & -79 & 256.9 & 386.7 & 735.1 \\
\hline 2011 & 4261.1 & 14346 & 10739.2 & -118.1 & 314.4 & 458 & 189.6 \\
\hline 2012 & 2971 & 12038 & 9543 & -294 & 433 & 337 & 1448 \\
\hline Years & $\begin{array}{c}\text { Outbound } \\
\text { investmen } \\
\mathrm{t}\end{array}$ & $\begin{array}{l}\text { Investment } \\
\text { in China }\end{array}$ & $\begin{array}{c}\text { Stock } \\
\text { investmen } \\
\mathrm{t}\end{array}$ & $\begin{array}{c}\text { Other } \\
\text { investme } \\
\text {-nts }\end{array}$ & $\begin{array}{l}\text { Net } \\
\text { errors }\end{array}$ & $\begin{array}{c}\text { Comprehensiv } \\
\text { e income and } \\
\text { expenditure }\end{array}$ & $\begin{array}{c}\text { Increase or } \\
\text { decrease in } \\
\text { reserve assets }\end{array}$ \\
\hline 2003 & 9.2 & 384 & -39.9 & -315.3 & -117.4 & 106.9 & -106.9 \\
\hline 2004 & 68.9 & 442.4 & -194.1 & 168.8 & -48.6 & 473.3 & -473.3 \\
\hline 2005 & 25.2 & 493.1 & -103.4 & -41.1 & 77.9 & 755.1 & -755.1 \\
\hline 2006 & -1.5 & 470.8 & 114.3 & -58.8 & 184.7 & 1170.2 & -1170.2 \\
\hline 2007 & 18.1 & 549.4 & 196.9 & 379.1 & 270.5 & 2063.6 & -2063.6 \\
\hline 2008 & 113.1 & 791.3 & -49.3 & -40.3 & -167.7 & 2070.2 & -2070.2 \\
\hline 2009 & 211.6 & 780.9 & -675.6 & 132.6 & -129.5 & 2469.8 & -2469.8 \\
\hline 2010 & 170 & 1384.1 & 186.7 & -696.8 & 164 & 4617.4 & -4617.4 \\
\hline 2011 & 534.7 & 1477.9 & 426.6 & -1210.6 & -260.9 & 4189.8 & -4189.8 \\
\hline 2012 & 439 & 782 & 387 & 679 & -435 & 3984 & -3984 \\
\hline
\end{tabular}

\subsection{Modeling and Solution of Principal Component Analysis}

In this paper, we firstly normalize the known data in table 1, form a matrix by the resulting data and solve the average of each column $Q=\sum_{i=1}^{n}\left(y_{i}-\overline{y_{i}}\right)^{2}$.Then we obtain the correlation coefficient matrix $r$, and solve the characteristic equation $|\lambda I-R|=0$. Eigenvalues $\lambda_{i}(i=1,2,3, \ldots p)$ are obtained and arranged them in the order of their sizes, and then the corresponding eigenvalues $e_{i}(i=1,2,3, \ldots . . p)$ of eigenvectors $\lambda_{i}$ are obtained. Calculate the contribution rate of each component $g$ and the cumulative contribution rate $\lg$. Then we can determine the number of principal components according to principle which the cumulative contribution rate of is more than $85 \%$. And then calculate the principal component load $l$, calculate the score of each principal component csum by the load. Have an economic analysis on each principal component and have a ranking based on scoring. Then make 
a comparison among 10 years of international income. Finally, classify the balance of payments risk index in view of the balance of payments risk index and its critical value, and get its comprehensive score. Determine the degree of risk of balance of payments by its comprehensive score. Score the forecast range of international balance of payments risk index and risk status and predict the future risk of balance of payments.

(1) Solve the correlated coefficient matrix

Firstly, normalize the known data of international balance of payments, obtain a matrix of 10 by 14 orders, solve the average of each column $\overline{x_{i}}$, and then calculate the correlation coefficient matrix:

$$
r=\left[\begin{array}{cccc}
r_{11} & r_{12} & \ldots & r_{1 p} \\
r_{21} & r_{22} & \ldots & r_{2 p} \\
\ldots & \ldots & \ldots & \ldots \\
r_{p 1} & r_{p 2} & \ldots & r_{p p}
\end{array}\right] .
$$

In which $r_{i j}(i, j=1,2,3, \ldots p)$ is the correlation coefficient of the original variable $x_{i}$ and $x_{j}$, the formula is:

$$
r_{i j}=\frac{\sum_{k=1}^{n}\left(x_{k i}-\bar{x}_{i}\right)\left(x_{k j}-\overline{x_{j}}\right)}{\sqrt{\sum_{k=1}^{n}\left(x_{k i}-\overline{x_{i}}\right) \sum_{k=1}^{n}\left(x_{k j}-\overline{x_{j}}\right)}}
$$

So we get the correlation coefficient matrix of the international balance of payments.

(2) Solve the characteristic equation

Firstly, the solve eigenvalue equation $|\lambda I-R|=0$, and get the eigenvalues $\lambda_{i}(i=1,2,3, \ldots p)$ of the international payments and rank them in the order of their sizes, that is $\lambda_{1} \geq \lambda_{2} \geq \lambda_{3} \geq \ldots . \geq \lambda_{p} \geq 0$. Then get respectively the corresponding eigenvectors $e_{i}(i=1,2,3, \ldots, p)$ of the eigenvalues $\lambda_{i},\left\|e_{i}\right\|=1$ is required, that is $\sum_{j=1}^{p} e_{i j}{ }^{2}=1$.In which $e_{i j}$ denotes the component $j$ of the

\begin{tabular}{|c|c|}
\hline $\mathrm{i}$ & eigenvalues \\
\hline 1 & 9.1564714 \\
\hline 2 & 2.3768169 \\
\hline 3 & 1.4646232 \\
\hline 4 & 0.776484 \\
\hline 5 & 0.1256188 \\
\hline 6 & 0.0525935 \\
\hline 7 & 0.0368357 \\
\hline 8 & 0.0098087 \\
\hline 9 & 0.0007478 \\
\hline 10 & $1.00 \mathrm{E}-15$ \\
\hline 11 & $1.60 \mathrm{E}-17$ \\
\hline 12 & $8.59 \mathrm{E}-16$ \\
\hline 13 & $-9.25 \mathrm{E}-17$ \\
\hline 14 & $-1.00 \mathrm{E}-15$ \\
\hline
\end{tabular}
vector $e_{i}$. The result is:

(3) Calculate the contribution rate of each principal component and cumulative contribution rate , and determine the principal component 
The contribution rate of principal component $F_{i}$ is $\frac{\lambda_{i}}{\sum_{k=1}^{p} \lambda_{k}}(i=1,2,3, \ldots, p)$, The cumulative contribution rate is $\frac{\sum_{k=1}^{i} \lambda_{k}}{\sum_{k=1}^{p} \lambda_{k}}(i=1,2,3, \ldots, p)$, then we get :

$$
\begin{aligned}
& \lg _{1}=0.654, \lg _{2}=0.8238, \lg _{3}=0.9284, \lg _{4}=0.9839, \lg _{5}=0.9929, \\
& \lg _{6}=0.9966, \lg _{7}=0.9992, \lg _{8}=0.9999, \lg _{9}=\lg _{10}=\ldots=\lg _{14}=1
\end{aligned}
$$

According to the principle of $\lg _{i} \geq 85 \%$, we select the three principal components.

(4) Calculate the load of each index and the score of each principal component

The calculation formula is $l_{i j}=p\left(F_{i}, x_{j}\right)=\sqrt{\lambda_{i}} e_{i j}(i, j=1,2,3, \ldots, 14)$ and calculates the score csum of each principal component from the load. As shown in Table 3.

Table 3: score of principal components of the balance of payments

\begin{tabular}{cccccc}
\hline$i$ & 1 & 2 & 3 & 4 & 5 \\
\hline csum & 11.3487 & 9.7061 & 8.2357 & 5.7285 & 0.6608 \\
\hline$i$ & 6 & 7 & 8 & 9 & 10 \\
\hline csum & -0.1103 & 2.0687 & -9.6433 & -11.6015 & -16.3927
\end{tabular}

According to the principal component analysis and score, we can know that foreign trade in imports, exports, total investment, capital and financial projects in play a important role in the balance of payments. When the international balance of payments risk becomes high, the state should first take these indicators into account of the macro-control, in order to reverse situation timely and minimize losses. To some extent, the three principal components explain the influence of the imbalance of international payments on trade balance, money supply and external net assets.

\section{Forecast of Balance of International Payments Risk}

The risk of balance of payments is a risk that occurs when the international balance of payments deteriorates, including the risks of the balance of payments itself and the adverse effects on the macroeconomic performance. According to the relevant theory of risk forecasting and early warning, the most basic element of the balance of payments risk forecast is to determine the relevant risk indicators of balance of payments. By observing these indicators, analyze and test abnormal changes in the balance of payments, and then forecast the possible risk of balance of payments and the uncertainty of the macroeconomic operation which it causes.

Based on the BOP risk index and its critical value, as well as the comprehensive score of the risk index system of balance of payments, this paper classifies the BOP risk index which is shown in Table 8. In this paper, the international risk is divided into five levels: safe, safer, general, less dangerous and dangerous, the relevant risk index of balance of payments is from 1 to 5 , the corresponding comprehensive score interval is given in Table 4. Which international balance of payments risk index becomes from low to high means that the risk of international balance of payments continues to increase. 
Table 4 Division of Balance of Payments Index

\begin{tabular}{cccl}
\hline Risk level & $\begin{array}{c}\text { Risk } \\
\text { index }\end{array}$ & $\begin{array}{c}\text { Comprehensive } \\
\text { score }\end{array}$ & \multicolumn{1}{c}{ meaning } \\
\hline safe & 1 & $0 \sim 4$ & $\begin{array}{l}\text { Moderate income and expenditure } \\
\text { Relatively moderate income and expenditure, there } \\
\text { will be no high risk }\end{array}$ \\
gafer & 2 & $5 \sim 8$ & $\begin{array}{l}\text { There is a certain risk of income and expenditure, and } \\
\text { there are effects on macro-economy }\end{array}$ \\
$\begin{array}{c}\text { less } \\
\text { dangerous }\end{array}$ & 3 & $9 \sim 12$ & $\begin{array}{l}\text { We must immediately pay attention income and } \\
\text { expenditure risks, and take measures to adjust risk } \\
\text { The risk of income and expenditure is extremely } \\
\text { great and urgent measures should be taken to rectify } \\
\text { it }\end{array}$ \\
\hline
\end{tabular}

In the process of forecasting the risk of balance of international payments, the forecast range of risk index of the balance of payments is determined according to the economic development situation, and then the risk status of the BOP risk index and its corresponding comprehensive score are determined. According to the comprehensive score, the risk level of balance of payments is determined. The forecast provide time and strategy to regulate and control for the state, and avoid the harm to the macro-economy caused by the risks.

\subsection{Forecast of Balance of Payments Risk in 2014}

Based on 2011, 2012 and the balance of payments in 2014, firstly predict the range of risk indicators of balance of payments in 2014, and determine the risk status in view of the forecast range. Finally, the scores of the risk indicators are given, and add the scores to get the comprehensive scores. Here are the scores given: 0 points for safety; 1 point for attention; 2 points for risk. As is given in Table 5 .

Table 5 Range Forecast of Risk Index of the Balance of Payments for 2014 and its risk status

\begin{tabular}{lccc}
\hline \multicolumn{1}{c}{ Risk indicators } & $\begin{array}{c}\text { Prediction } \\
\text { interval }\end{array}$ & Risk status & The scores \\
\hline Export growth rate & $10 \% \sim 15 \%$ & safety & 0 \\
FDI growth rate & $3 \% \sim 5 \%$ & attention & 1 \\
Trade Balance /GDP & $3 \% \sim 6 \%$ & attention & 1 \\
$\quad$ FDI+ Current account $) / G D P$ & $3 \% \sim 5 \%$ & safety & 0 \\
Opening to the outside world & $50 \% \sim 60 \%$ & risk & 2 \\
Changes in International Reserves /GDP & $5 \% \sim 6 \%$ & attention & 1 \\
Changes in International Reserves / & $40 \% \sim 50 \%$ & risk & 2 \\
Changes in Base Currency & & \\
\hline
\end{tabular}

Add scores of the BOP risk indicator in Table 9, we obtain a comprehensive score range of 6 points for risk system of the balance of payments in 2014, and the corresponding BOP index level is safer. That is balance of payments is relatively modest in 2014, and there will be no high risk.

\section{Conclusions and Recommendations}

From the principal component analysis, we can see that foreign trade in imports, exports, total investment and capital and financial items have a crucial impact on the balance of payments. At the same time, the three principal components also explain the influence of the imbalance of international payments on trade balance, money supply, and net assets to a certain extent. Therefore, in the risk 
management on China's balance of payments imbalances, first of all, we should achieve balance of payments internal balance, and correctly deal with investment and consumption, the relationship between domestic demand and external demand. We should actively expand domestic demand, and strive to reduce export dependence, and gradually reduce the current account balance. Secondly, we should further expand China's foreign investment strategy, and guide domestic enterprises to invest overseas. We also should make rational allocation of foreign exchange assets and reduce the balance of payments risks. Thirdly, in the prevention of balance of payment risks, we should further improve the management of floating exchange rate according to the principle of "active, gradual and available", and gradually increase the flexibility of RMB exchange rate to rationally guide capital flow. And we should strengthen monitoring on short-term capital flow, and suppress frequent inflow and outflow of speculative hotlines to reduce the impact on China's domestic economy. China must adjust foreign investment, foreign trade and industrial policies as soon as possible, and further control the management of imbalanced risks of international payments.

The basic path and countermeasures to achieve China's balance of payments is to convert China's economic growth mode to rely mainly on domestic demand, and find the driving force of economic growth through reform, transformation and innovation. And we should improve income distribution, improve financial efficiency, and accelerate the pace of factor market reform. And we also should improve and perfect the existing policies of current project management, capital project management and foreign exchange reserve management. At the same time, through the implementation of the strategy of "the Belt and Road Initiative ", we can promote China's balance of payments balance. The model established in this paper can also forecast the balance of payments risks accurately and provide reference for China to prevent the balance of payments risks. It can also be extended to the prediction of economic operation risks, fiscal risks, and employment risks and so on.

\section{References}

[1] J. Han: China's international imbalance of payments, the huge "double surplus" and Solution. South China Finance.vol. 12(2011), pp. 26-31.

[2] J. S. Shi:A study on China's international balance of payments: reasons of imbalance and balance countermeasures. Yunnan University(2016).

[3] K. Chao, J.S. Li: The Causes of China 's imbalance of payments and the countermeasures. Shandong Social Sciences. vol.2(2013), pp. 160-164.

[4] T.L. Chen, Z.L. Shao: A study on the causes, effects and rebalancing mechanism of the double surplus in China 's balance of payments . Financial Theory \& Practice. vol.5(2012), pp. 77-81.

[5] Y.L.Zhao: An Empirical Study of China's Trade Imbalance. Southwestern University of Finance and Economics(2012).

[6] X.Cai. in:The Impact of FDI on Balance of Payments, edited by Economic Science Publishing(2011).

[7] C. Jiang, H. Wu: China's imbalance of international payments: a new perspective based on income distribution. Research on Financial and Economic Issues. vol. 10(2009), pp. 24-36.

[8] M.Z.Zhang,J.Ma: A Theoretical Analysis and an Empirical Study on Impact of Industrial Structure on China's Trade Imbalance . Journal of International Trade. vol. 1(2012), pp. 50-61.

[9] C.C.Ding,L.J.Zhsang: Why fast growth Can Coexist with Surplus of Balance-of -payments in China:A Monetary Approach. Finance \& Economics. vol.4(2010), pp. 32-40.

[10] J. W. Li, B.P. Ren: Imbalance of international payments, economic fluctuations and quality of China's economic growth. Contemporary Finance \& Economics. vol. 1(2013), pp. 23-31.

[11] J. Dai: A research of risk monitoring and warning system of international payments surplus-type imbalance. Nanjing Agricultural University(2011). 
[12] X.S.Ren,X.L.Yu. in:Multivariate Statistical Analysis, edited by China Statistics Press(2011). 